\title{
Narratologiese ondersoek en eksegese van die boodskap van die evangelies
}

\author{
Ina Gräbe
}

\begin{abstract}
Narratological investigation and exegesis of the message of the gospels This paper argues that the narrative structure of the gospels facilitates the communication of the Biblical message and that exegesis of this message therefore presupposes an assessment of the semantic implications revealed through an analysis of particular genre conventions utilized in the narration of Biblical material. The narrative structure of the gospels shows striking correspondences with basic narrative forms such as fairy tales, so that an analysis of the narrative material on the basic story level, rather than on the level of narrative presentation, seems appropriate. In fact, the correspondence between the levels of story and narrative (Genette 1980) ensures that the deep structure or story content is directly projected onto the surface structure of the narrative text, resulting in a clear communication of the Biblical message.
\end{abstract}

\section{INLEIDING}

\subsection{Die neerslag van literatuurteoretiese beginsels in navorsing oor aspekte van die Bybel}

Resente studies rondom die vraagstuk van 'n adekwate(r) eksegese van die boodskap van die evangelies toon 'n steeds groeiende (en myns insiens verblydende) besef onder Bybelnavorsers van die noodsaaklikheid van ' $n$ kennisname van literêr-teoretiese beginsels in ' $n$ ondersoek van die Bybel as ' $n$ nagelate geskrewe dokument met 'n spesifieke kommunikatiewe doel en funksie. 'n Belangstelling in literêre verskynsels by akademici wat hulle met die Bybel besig hou, is vir literatore natuurlik niks vreemds nie, aangesien die omgekeerde situasie lank reeds in literêre kringe geld - kennis van die Bybelteks word as van-

\footnotetext{
" Referaat gelewer by die NTWSA subgroep-LiVTRed, Universiteit van Pretoria op 24 Mei 1985. Die artikel moet saamgelees word met dié oor narratiewe tegnieke en vergelykingskonstruksies in die gelykenis van die barmhartige Samaritaan wat in HTS $42 / 2$ (1986) gepubliseer gaan word.
} 
selfsprekend veronderstel vir die begrip van Bybelse verwysings binne die literatuur. Die verwantskap tussen die Bybelteks en literêre tekste betrek egter nie net tematiese nie, maar veral ook strukturele aspekte, aangesien al drie die hoofgenres van die literatuur in die Bybel verteenwoordig word. In hierdie verband sou 'n mens immers daarop kon wys dat die Psalms van die mooiste poësie in die wêreldliteratuur bevat, dat 'n gelykenis soos dié van die verlore seun al as 'n model kortverhaal getipeer is en les bes dat dramatiese gebeure met konfliksituasies tussen mens en natuur, mens en mens en ook mens en God skering en inslag van die hele Bybel vorm.

Die vraag na die funksie van literêre strukture en kwaliteite volg noodwendig op 'n erkenning van die aanwesigheid van herkenbare literêre genres in die Bybel. Tensy daar uitgegaan word van die teen hierdie tyd hopelik verouderde standpunt dat die literêre aspekte van die Bybelteks hoogstens dekoratief kan wees en daarom irrelevant is vir'n dekodering van die Bybelse boodskap, lei die vraag na die funksie van literêre strukture in die Bybel noodwendig na ' $n$ kennisname van literatuurteoretiese uitgangspunte en navorsing op die gebied van spesifieke genrekonvensies.

Vir die doeleindes van hierdie referaat beperk ek die ondersoek na die funksie van genrekonvensies in die Bybel graag op versoek tot narratiewe strukture in die Nuwe Testament. Die funksie van narratiewe konvensies sal toegelig word met verwysing na kernaspekte van resente semio-strukturalistiese narratologiese studies en hulle potensiële relevansie vir Bybelse eksegese.

\subsection{Plasing van narratologiese teorieë binne 'n kommunikasiemodel}

Die basiese kommunikatiewe situasie in die literatuur kan met behulp van die volgende vereenvoudigde diagram voorgestel word:

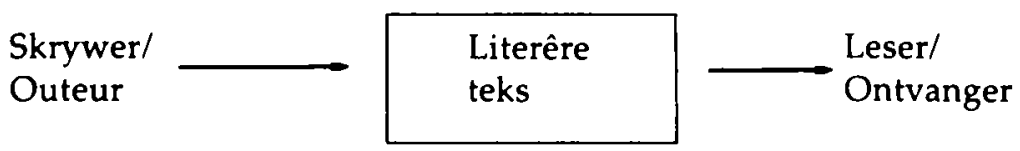

$\mathrm{Na}$ analogie van enige kommunikatiewe taalsituasie waar 'n spreker 'n boodskap tot ' $n$ aangesprokene rig, word in die bostaande diagram veronderstel dat daar in 'n literêre kommunikatiewe situasie 'n skrywer of outeur is wat die literêre teks tot 'n leser of ontvanger rig. Hierdie 
vereenvoudigde voorstelling van die literêre kommunikasiesituasie kan meer genuanseer weergegee word met behulp van Jakobson (1960) se bekende kommunikasiemodel vir alle taalsituasies met sy ses faktore en ses ooreenstemmende funksies:

(2)

Faktore:

$\begin{array}{ll} & \text { KONTEKS } \\ \text { SENDER } & \text { BOODSKAP }\end{array}$

KONTAK

KODE

ONTVANGER

Funksies:

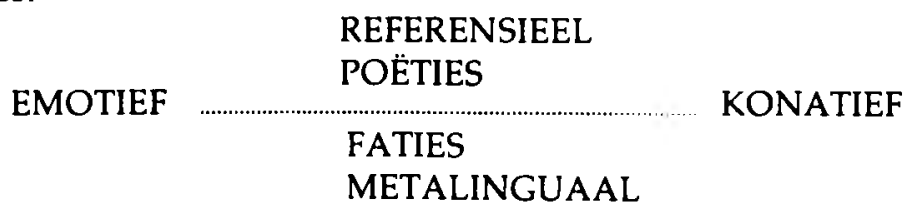

Volgens Jakobson (1960: 353) is daar altyd ses faktore teenwoordig in enige vorm van verbale of talige kommunikasie: die sender rig 'n boodskap (die teks self) tot 'n ontvanger; hierdie boodskap verwys na 'n konteks of werklikheid, dit is gestel in 'n kode en dit word oorgedra deur middel van ' $n$ bepaalde kanaal, wat die kontak tussen sender en ontvanger verteenwoordig. Afhangende van watter faktor in die kommunikasiesituasie voorrang geniet, word telkens 'n ander funksie geaktiveer: die emotiewe of ékspressiewe funksie reflekteer die sender se houding, terwyl die konatiewe funksie die bedoelde effek van die teks op die ontvanger registreer; die referensiële funksie verwys na die ontvanger se voorstelling van die konteks van die boodskap of teks; die metalinguale funksie trek die aandag op die kode waarin die teks aangebied word; die fatiese funksie toets die effektiwiteit van die gesprekskanaal en die poëtiese funksie word geaktiveer wanneer die teks of boodskap self vooropgestel word. Jakobson se poëtiese funksie kan wyer opgeneem word en het betrekking op alle literêre tekste en is nie beperk tot die poësie alleen nie. 'n Aktivering van hierdie funksie het bepaalde implikasies vir die oordra van die boodskap in ' $n$ kommunikasiesituasie: kommunikasie geskied op ' $n$ indirekte manier, as ' $t$ ware déúr die struktuur, omdat aandag opgeëis word vir die teks as teks en die taal dus as 't ware 'ondeursigtig' en 'ikonies' word. In nie- 
literêre tekste, waar die poëtiese of literêre funksie nie dominant is nie, is die taal deursigtig en die kommunikasie onmiddellik bevatlik. Die dekodering of interpretasie van enige literêre teks sal volgens die bostaande redenasie dus noodwendig 'n noukeurige analise verg van die kommunikatiewe waarde van literêre strukture en van die semantiese implikasies van genrekonvensies.

Indien daar dus van die veronderstelling uitgegaan word dat literêre strukture en genrekonvensies in die Bybel funksioneel aangewend word, dit wil sê nie bloot as versiering nie, het so 'n aanname ingrypende implikasies vir die dekodering van die Bybelse boodskap. Die ontvanger van hierdie boodskap sou dan eerstens oor die kennis moes beskik om literêre strukture te herken en tweedens sou hy ook die kompetensie moes hê om sodanige strukture te dekodeer. Die vraag ontstaan of ontvangers van die Bybelse boodskap wat nie oor die bogenoemde kennis en kompetensie beskik nie, wel in staat is om iets van die Bybelse boodskap te begryp, met ander woorde of kommunikasie van Bybeltekste wat ooreenstemming met literêre tekste vertoon, geheel en al afhanklik is van literêre genrekonvensies vir begrip en of sodanige gedeeltes ook buite om die literêre struktuur kan kommunikeer en indien wel of dit dieselfde boodskap kommunikeer. Dit lyk my 'n vrugbare debatspunt vir toekomstige eksegetiese studies.

Die bogenoemde vrae hang baie nou saam met die funksies wat in Jakobson (1960) se kommunikasiemodel geaktiveer word. Resente narratologiese teorieë is nog hoofsaaklik semio-strukturalisties georiënteerd met die gevolg dat die klem op die literêre (poëtiese) en metalinguale funksies val, met die klem in resepsieteorieë ook op die konatiewe funksie en die rol van die leser in die konkretisering van die estetiese objek. Op die oomblik lyk lesergerigte benaderings met 'n gesonde respek vir die grense en moontlikhede van die teks vir my na die bruikbaarste raamwerk vir eksegetiese studies. Die nuutste narratologiese teorieë is in ieder geval nog semiostrukturalisties georiënteerd en die rol van die leser word ook semioties verantwoord (Eco 1979). Die implikasies van 'n dekonstruksie-benadering vir die begrip of (relativering!) van strukture binne die Bybel verg ' $n$ aparte studie en word nie in hierdie referaat aangeraak nie.

Vervolgens kan die kommunikasiesituasie van narratiewe tekste aan die hand van die volgende diagram (Van Luxemburg, Bal \& Weststeijn 1983: 156) toegelig word: 


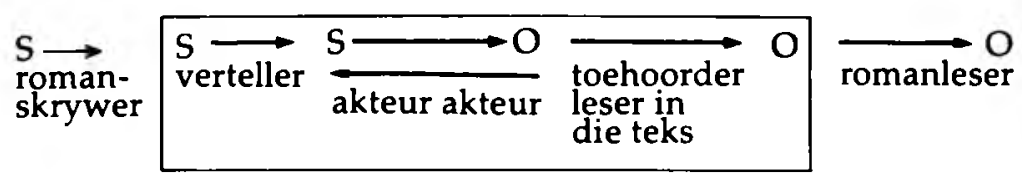

$\mathrm{S}=$ sender

$\mathrm{O}=$ Ontvanger

$\square=$ grense van die narratiewe teks

$\rightarrow=$ rigting van die kommunikasie

Belangrik in hierdie diagram is die feit dat daar ' $n$ hiërargiese ordening te bespeur is: die woorde van die akteurs binne die fiktiewe wêreld is ingebed in dié van die verteller binne die narratiewe teks; die verteller is die primêre woordvoerder wat soms die woord kan afstaan aan ' $n$ sekondêre woordvoerder of woordvoerdgrs binne die fiktiewe wêreld. In ' $n$ vereenvoudigde voorstelling van die kommunikasiesituasie van verhalende tekste tree die primêre woordvoerder of verteller op as ' $n$ tussenganger tussen twee wêrelde: die fiktiewe wêreld van die akteurs word deur die bemiddeling van die verteller toeganklik gemaak vir die werklike leser van die narratiewe teks in sy reële wêreld. Die verteller binne ' $n$ narratiewe teks het egter ook nog ' $n$ verdere funksie: die leser se interpretasie van die fiktiewe wêreld word gerig deur die vertellersteks omdat die verteller se verslag van die gebeure en sy weergawe van die akteurs se werklike woorde gewoonlik nie sonder duidelike of bedekte kommentaar is nie.

Wanneer aanvaar word dat die evangelies narratiewe tekste is, is die eerste belangrike aanpassing wat gemaak moet word, natuurlik dat hulle nie fiksionele of fiktiewe narratiewe tekste is nie, maar veronderstel is om 'n weergawe te wees van historiese gebeure. Wat die hiërargiese ordening betref, is die funksie van die primêre woordvoerders of vertellers egter net so sentraal as in 'n fiksionele narratiewe teks: die vertellers Matteus, Markus, Lukas en Johannes kleur die ontvanger van die evangeliese boodskap se indrukke van die vertelde gebeure en van die weergawe van die akteurs onder wie Christus dan natuurlik die hoofakteur binne die vertelde geskiedenis is. Vergelyk in hierdie verband ook die hiërargiese ordening in diagram (4) vir onderskeidelik fiksionele en historiese narratiewe tekste. 
(4)
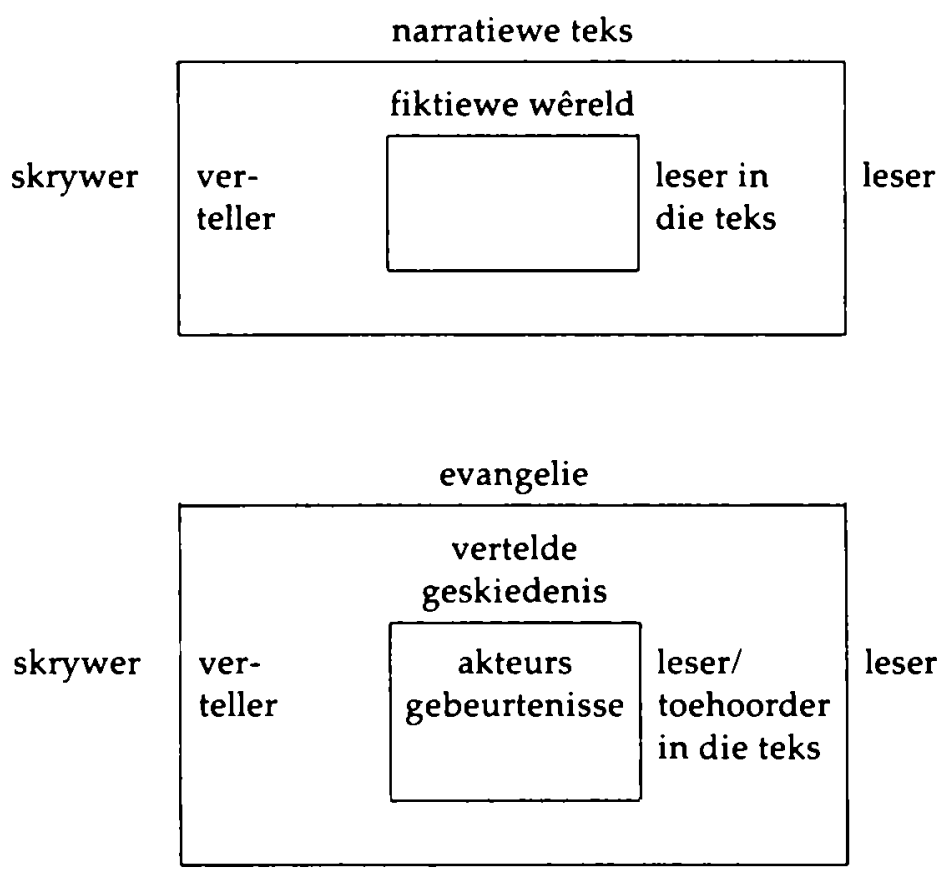

Dit volg uit die voorafgaande opmerkings dat 'n narratiewe teks saamgestel is uit twee hoofkomponente: daar is ' $n$ reeks gebeure om te vertel en daar moet iemand wees wat hierdie gebeure aan die ontvanger buite die narratiewe teks oordra. Die benaming narratiewe teks (wat 'n vertaling is van Gérard Genette se Narrative Discourse uit die Frans Figures III) impliseer reeds 'n storie en 'n vertelhandeling soos in diagram (5) gesien kan word:

(5)

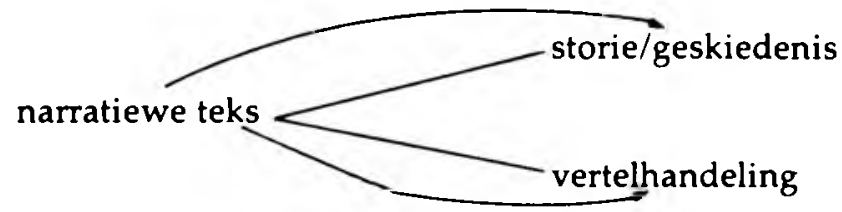

Die teks kan nie verhalend of narratief wees tensy daar ' $n$ reeks gebeure is wat ' $n$ storie of geskiedenis vorm nie; dit kan ook nie 'n teks wees tensy daar ' $n$ verteller of skrywer is wat die storie of geskiedenis aan'n ontvanger oordra nie. 
Genette (1980) onderskei na aanleiding van die term narratiewe teks die volgende drie vlakke in enige verhalende teks, wat soos volg vertaalbaar is:

(6)

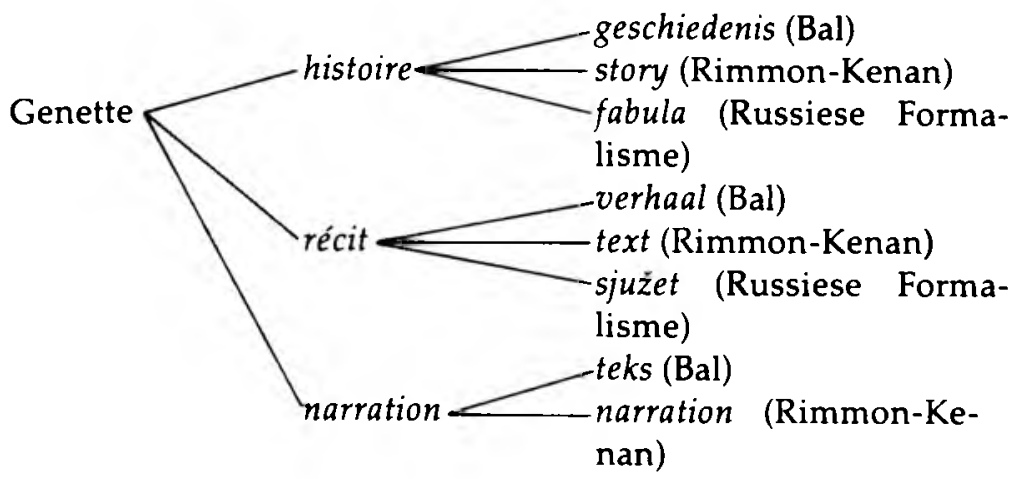

Hierdie drie vlakke kan vervolgens kortliks behandel word en hulle moontlike relevansie vir 'n narratologiese lesing van die evangelies terselfdertyd nagegaan word.

\section{ELEMENTE VAN DIE STORIE OF GESKIEDENIS}

\subsection{Inleidende opmerkings}

Die storie of geskiedenis verwys na die vertelde gebeure wat geabstraheer is van hulle rangskikking in die teks en gerekonstrueer word in hulle chronologiese orde. Die storie of geskiedenis kan dus gedefinieer word as 'n reeks chronologies- en logies-samehangende gebeure tesame met die akteurs wat deel het in hierdie gebeure.

Waar storie ' $n$ opeenvolging van gebeurtenisse is, is die verhalende teks 'n gesproke of geskrewe diskoers waarin die vertelling van die gebeure in die storie of geskiedenis onderneem word. Die verhaal of narratiewe teks is met ander woorde dit wat ons lees. In hierdie verband sou die evangelies dus bestempel kon word as narratiewe tekste wat die vertelling van die gebeure vanaf Christus se geboorte tot sy kruisiging en opstanding op aarde vertel. In ' $n$ fiksionele teks is dit egter deel van die genrekonvensie dat die vertelling van die gebeure nie noodwendig in 'n chronologiese orde geskied nie. Trouens, dit is een van die belangrikste aspekte van die narratiewe teks dat tydsafwykinge funksioneer om bepaalde interpretatiewe leidrade aan die leser 
te verskaf vir 'n dekodering van die teks. Slegs in meer primitiewe vorme, soos onder andere die sprokies wat Vladimir Propp ondersoek het, word die chronologiese opeenvolging nie onderbreek nie en val fabula en sjužet saam. In hierdie opsig verskil die evangelies nou van die meeste fiksionele narratiewe tekste, deurdat streng gehou word by die chronologiese aanbieding van die gebeure, soos gesien kan word uit die volgende opsomming van die hooftrekke van Matteus, soos in die Nuwe Afrikaanse Bybelvertaling aangegee:

(7)

Die hooftrekke van die boek

Die geslagsregister en geboorte van Jesus 1-2

Doop en versoeking van Jesus 3-4

Die bergrede 5-7

Wonders deur Jesus 8-9

Die sendingopdrag 10

Gesprekke met teenstanders 11-12

Gelykenisse oor die koninkryk 13

Wonders en gesprekke met die Fariseërs 14-17

Die betekenis van dissipelskap 18

Van Galilea af tot in Jerusalem 19-23

Die koms van die koninkryk 24-25

Jesus se lyding, dood en opstanding 26-28

Alle items van die narratiewe of verhalende inhoud word aangebied vanuit ' $n$ bepaalde perspektief. In hierdie verband onderskei Genette (1980) tussen 'n fokalisator (hy wat sien) en 'n verteller (hy wat vertel). In 'n verhaal word die gebeure en die akteurs van die geskiedenis op 'n bepaalde manier gefokaliseer. In hierdie verband is dit interessant dat die eksegeet die geleentheid het om te vergelyk hoe dieselfde geskiedenis en dieselfde akteurs deur vier verskillende fokalisators aangebied word. Wat hulle sien en hoe hulle sien, sou in hierdie verband interessante perspektiewe kon open.

Die derde aspek van die narratiewe teks is die vertelhandeling self daar moet in ' $n$ verbale verhaal iemand wees wat die teks uitspreek of skryf - in hierdie verband is daar dan weer vier verskillende 'opskrywers' van dieselfde gebeure en akteurs in die vier evangelies, maar almal selekteer nie dieselfde gebeure om oor te vertel nie.

Hierdie drie aspekte van narratiewe tekste: die storie, verhaal en vertelhandeling kan vervolgens kortliks uiteengesit word met die 
moontlike implikasies vir 'n studie van die narratiewe aspekte van die evangelies daarby aangestip.

\subsection{Storie en gebeure}

Omdat die storie geabstraheer word uit die narratiewe teks, is dit nie direk toeganklik vir die leser nie. Ten opsigte van die evangelies kan die storie of geskiedenis gesien word as die hele lewe van Christus van sy geboorte tot sy dood en opstanding en opvaar na die hemel, insluitende dié dele wat nie in die evangelies vertel word nie. 'n Vraag wat natuurlik onmiddellik hier ontstaan, is of dit enigsins wenslik en/of sinvol sou wees om die geskiedenis uit die vertelde verhaal te probeer abstraheer. Rimmon-Kenan (1983: 8) stel die noodsaak om met die storie of geskiedenis te begin soos volg: 'Starting with story, rather than with the text from which it is abstracted, the former may be grasped as transferable from medium to medium, from language to language, and within the same language.' In die geval van die vier evangelies kan die geskiedenis van Christus dan wel geabstraheer word as iets wat oordraagbaar is tussen vier verskillende vertellers wat die geskiedenis aanbied in vier verskillende fokaliserings. Die groot lyne van dié deel van Christus se geskiedenis op aarde wat wel vertel word, val uiteen in 'n aantal gemeenskaplike dade wat almal dui op wonderwerke van òf genesing van mense ò stryd met duiwelse magte aan die een kant en 'n aantal woorde wat lerend is aan die ander kant. Dit val op dat hierdie 'materiaal' nie tipies is van dié gebeure wat normaalweg die grondstof van 'n storie sal vorm nie - daar is geen afwisseling, voortgang of spânningsmoontlikhede nie. Tog word hierdie gebeure vertel, sodat hier aangeneem kan word dat die kommunikasie van die boodskap kan profiteer deur die aanbieding daarvan in storievorm of asof dit 'n storie sou kon wees. Dit gaan hier om die moontlikhede van die storie as 'n kommunikasiemiddel en nie die fiksionele (= nie ware) aard daarvan nie.

Dit is eintlik onmoontlik om uit hierdie groot aantal eendersoortige dade enige chronologiese beginsel af te lei: Is daar enige rede waarom die reiniging van die tempel voor die vervloeking van die vyeboom in Matteus en juis andersom in Markus vertel word? Is dit vir die leser moontlik om uit die vertelde twee narratiewe tekste die chronologiese volgorde te abstraheer? Dit lyk asof hierdie reeks eenderse gebeure net sowel opgenoem as vertel kon gewees het. Die keuse van vertelling as aanbieding laat daarom die vermoede ontstaan dat dit intuïtief deur die vier evangelieskrywers aangevoel word as 'n effektiewe kommuni- 
kasiemiddel. Hierdie vermoede word natuurlik gestaaf deur die feit dat binne die evangelies en ingebed in die groter strukture die gelykenisse ook nog aangebied word in die vorm van verhale - nie net Christus se dade nie, maar ook (sommige van) sy leerstellinge word dus doelbewus aangebied in die vorm van ' $n$ verhaal. Die feit dat die storievorm sowel oorkoepelend as intern in die evangelies aangewend word, is myns insiens genoeg motivering vir 'n tipering van die evangelies as 'verhale' en derhalwe 'n ondersoek na die moontlike funksies van die narratiewe vorm.

\subsection{Storie en akteurs}

In formalistiese en strukturalistiese modelle word karakters ondergeskik gestel aan gebeure en handeling (ook by Aristoteles). Propp se sewe rolle word deur Greimas (1966) gereduseer tot ses aktansiële rolle: (8)

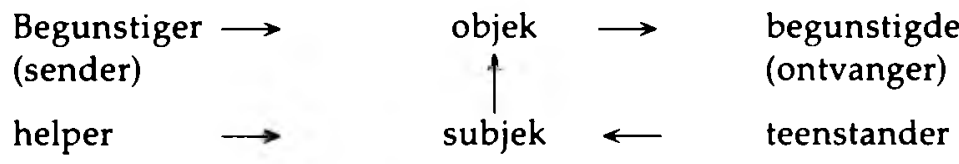

Greimas onderskei tussen akteurs en aktante: die eerste kan onbeperk in aantal wees, soos byvoorbeeld die menigtes wat Jesus in sy omswerwinge volg, of al die meedoeners aan en toeskouers van die verhoor en kruisiging is almal akteurs in die geskiedenis van Christus se omswerwinge op aarde. Daarenteen is die aantal aktante beperk tot ses rolle wat direk verbind word aan die funksie wat hulle in die geskiedenis verrig. Bal (1978: 33) verduidelik Greimas se definiëring van aktant soos volg:

'Een actant is een klasse van acteurs die een gemeenschappelijk kenmerk vertonen. Dat gemeenschappelijk kenmerk staat in verband met de hele geschiedenis, gezien als een naar een doel gerichte onderneming. Een actant is daarom een klasse van acteurs die allen dezelfde relatie onderhouden met het streven dat de kern vormt van de geschiedenis. Die relatie noemt Greimas de functie. $(F) .^{\prime}$

Dieselfde aktant kan uitgevoer word deur meer as een akteur - al die dissipels sou byvoorbeeld as Christus se helpers beskou kon word; daarenteen kan meer as een aktant ook setel in dieselfde akteur: Judas is aanvanklik as dissipel 'n helper en later as verraaier 'n teenstander. 
Aangesien die geskiedenis so belangrik is in die evangelies, kan Greimas se aktansiële rolle met vrug gebruik word om te onderskei tussen verskillende funksies wat deur die akteurs verrig word. Christus self is natuurlik die hoofakteur, die subjek of sender wat ' $n$ bepaalde doel nastreef, naamlik om die evangelieboodskap te bring aan mense op aarde - hulle is dus terselfdertyd die ontvangers of begunstigdes en ook die objek van die lering en dade wat uitgevoer word.

Die strewe van die subjek is dikwels nie voldoende om die objek te bereik nie. Daar is altyd magte wat dit moontlik maak of verhinder dat die subjek sy doel bereik. Greimas noem hierdie relasie destinateur en destinaire omdat dit om 'n vorm van kommunikasie gaan. RimmonKenan (1983: 35) vertaal hierdie terme met sender en ontvanger, terwyl Bal (1978: 34) dit vertaal met begunstiger en begunstigde. Bal verkies om nie sender te gebruik nie omdat 'n aktiewe deelname gesuggereer word wat lank nie altyd die geval is nie. Die begunstiger is dikwels 'n abstraksie, byvoorbeeld die maatskappy, die noodlot, die tyd, ensovoorts, maar kan ook die konkrete vorm van 'n persoon aanneem. In die evangelies sal die hoofbegunstiger waarskynlik God die Vader wees wat in ieder geval die subjek gestuur het met 'n bepaalde doel om iets op aarde te bereik. Waar die eerste vier relasies noodsaaklik is in enige geskiedenis - sonder aktante geen relasies, sonder relasies geen proses, sonder proses geen geskiedenis - is die helper en teenstander nie in elke geskiedenis noodsaaklik nie. Hierdie kategorieë sorg gewoonlik vir ontwikkeling in die verloop van die geskiedenis:

(9)

$\begin{array}{ll}\begin{array}{l}\text { begunstiger (sender) } \\ \text { het mag oor die hele } \\ \text { onderneming }\end{array} & \begin{array}{l}\text { helper } \\ \text { kan alleen toevallig tot } \\ \text { hulp kom }\end{array} \\ \begin{array}{l}\text { is dikwels abstrak } \\ \text { bly dikwels op die } \\ \text { agtergrond } \\ \text { meesal maar één }\end{array} & \text { tree na vore } \\ \end{array}$

Die geskiedenis van die evangelies sou aan die hand van die bostaande aktansiële rolle of funksies in breë trekke geanaliseer kon word. Veral aangesien dade of aksies so belangrik is in die evangelies en die gebeure daarom so 'n sentrale plek inneem, kan die aktansiële model waarskynlik' $n$ vrugbare analisemodel wees. 
Die feit dat die evangelies juis op hierdie eerste vlak van die geskiedenis goed analiseerbaar is, sê myns insiens iets vir die geslaagdheid van die verhalende vorm vir die oordra van die boodskap wat in die evangelies verkondig word. Die beswaar teen Propp en Greimas (ook Bremond) se 'grammatikas' van verhale is gewoonlik dat dit goed werk vir eenvoudige tipe verhale soos volksverhale of sprokies, dit wil sê die sogenaamde grondvorme van verhale, maar dat dit te rigoreus is om ingewikkelde artistieke romans mee te ontleed. Hierdie beswaar word in ' $n$ ondersoek na die verhalende karakter van die evangelies, of die evangelies aangebied in die vorm van verhale, egter myns insiens juis 'n voordeel: omdat gehou word by die basiese tipe verhaalvorm, is dit 'n geslaagde kommunikasiemiddel wat wye toeganklikheid verseker vanweë die intuïtiewe kompetensie waaroor taalgebruikers beskik om so ' $n$ basiese storie of geskiedenis te kan abstraheer. 'The theoretical possibility of abstracting storyform probably corresponds to the intuitive skill of users in processing stories: being able to re-tell them, to recognize variants of the same story, to identify the same story in another medium and so on. It is this intuition that has led almost every narratologist following in Vladimir Propp's footsteps to formulate a claim that an immanent story structure, sometimes called "narrativity" may be isolated at least for the sake of description' (Rimmon-Kenan 1983: 7).

'n Mens kan inderdaad sê dat feitlik 'n hele evangelie beslaan word deur ' $n$ basiese storievorm: enersyds die gebeure wat chronologies vertel word en die akteurs wat in duidelike aktansiële rolle uiteenval ten opsigte van Christus se omswerwinge op aarde; andersyds die rapportering van sy woorde in die vorm van stories in die gelykenisse, waar dieselfde tipe eenvoudige storievorm ten opsigte van gebeure en aktansiële rolle gehandhaaf word.

'n Ondersoek na die narratiewe karakter van die evangelies op hierdie eerste storievlak lyk my dus uiters sinvol. Dit is belangrik dat daar baie min verskil is tussen die dieptestruktuur (die storie) en die manier waarop dit aangebied word (die verhaal), omdat die boodskap dan duideliker bevatlik is - daar is minder werk vir die leser of ontvanger, die artistieke vorm bevorder kommunikasie eerder as om dit indirek en moeiliker te maak.

Hiermee verval ' $n$ moontlike beswaar in die aktivering van die literêre funksie wat hierbo genoem is met die bespreking van Jakobson (1960) se kommunikasiemodel. Die eis dat genrekonvensies in ag geneem word by die interpretasie van die boodskap maak die evangelies 
nie esoteries nie, want die basiese storievorm wat gekies word, bring juis ' $n$ evangeliese boodskap binne die bereik van die vermoë van enige tipe ontvanger - selfs, en miskien veral, ' $n$ kind. Die eenvoud en universaliteit van die basiese storievorm is funksioneel in die kommunikasiesituasie van die evangelies.

Dit bring my dan by die funksie van genre: Myns insiens is dit essensieel dat die ontvanger van die evangelietekste juis moet kan raaksien dat die verhaalvorm van sowel die lewensgeskiedenis van Jesus as die vorm van die gelykenisse ooreenstemming vertoon met basiese grondvorme van die verhaal - die sprokies of volksverhale wat al eeue lank deel van die kulturele skat van die mensdom is. Die geheim van die vertaalbaarheid van die evangelieboodskap en sy universele trefkrag lê in die kommunikatiewe waarde van die storievorm wat gekies is om die boodskap oor te dra.

\title{
3. ASPEKTE VAN DIE VERHALENDE TEKS
}

In artistieke verhale word die logies en chronologies samehangende gebeure van die storie of geskiedenis gewoonlik op ' $n$ bepaalde manier beïnloed deur die aspekte van tyd en karakter in die narratiewe teks: tyd kan gesien word as die tekstuele rangskikking van die gebeurekomponent van die storie; karakterisering is die aanbieding van die akteurskomponent van die storie. Die derde aspek in die narratiewe teks is fokalisasie, wat te make het met die 'angle of vision through which the story is filtered in the text, and it is verbally formulated by the narrator' (Rimmon-Kenan 1983: 43). Hierdie drie aspekte van die narratiewe teks toon aan hoe die verhaal verbind is aan enersyds die storie en andersyds die vertelhandeling self:

(10)

\author{
Verhalende teks \\ tyd \\ karakterisering \\ fokalisering
}

storie

vertelhandeling

Indien die hipotese waartoe daar in die vorige afdeling gekom is, juis is, behoort daar nie veel verskil te wees tussen die tydsaanbieding van die storie en die verhaal nie en waarskynlik sal die invul van die akteurs tot volwaardige karakters ook minder aandag kry. Met ander 
woorde: Die aanwending van tyd en die aktivering van karakteriseringstegnieke op hierdie vlak van die evangelies as verhale sal waarskynlik die ooreenkoms tussen storie en verhaal bevestig.

\subsection{Die verhaal en die tydsaspek}

Genette (1980) onderskei drie aspekte van tyd wat in die omvorming van storie tot verhaal of fabula tot sjužet geaktiveer word: volgorde, duur en frekwensie. In artistieke verhale word daar gewoonlik grootliks afgewyk van die chronologiese opeenvolging van die gebeure in die storie of die geskiedenis - die verhaal begin nie noodwendig by die begin nie en verander die volgorde van die gebeure deur middel van terugflitse en vooruitskouings. In die evangelies word hierdie tipe vervreemdingseffek (Russiese Formalisme) of middel tot vooropstelling egter bykans nooit benut nie. Die verhaal van Christus begin by sy geboorte of die aankondiging van sy geboorte en eindig met die beëindiging van sy lewe op aarde. Die middelgebeure word oënskynlik ook neergeskryf in die vorm en volgorde waarin dit voorgekom het. Hierdie nie-aktivering van 'n belangrike narratiewe konvensie is soos reeds hierbo betoog funksioneel, aangesien die storiekarakter van die verhale van die evangelies bevorderlik is vir kommunikasie.

Die tweede narratiewe tegniek word wel in die evangelies benut. In hierdie verband is die ritme van die verhale belangrik. Afhangende van die tyd wat in ' $n$ verhaal bestee word om ' $n$ sekere tydperk in die geskiedenis te vertel, kan onderskei word tussen 'n ellips, 'n samevatting, toneelmatige aanbieding, vertraging en pouse.

Die ellips verteenwoordig ' $n$ weglating in die verhaal van ' $n$ bepaalde deel van die geskiedenis. In die lewensverhaal van Christus word 'n klein deeltjie gewy aan sy geboorte, in een van die evangelies word 'n episode uit sy kinderjare aangehaal, en die res van sy lewe voor sy dertigste jaar word feitlik geheel en al verswyg. Die konsentrasie op wat in sy volwasse lewe gebeur - die drie jaar van sy omswerwinge in Israel - toon die ondergeskiktheid van karakter aan funksie wat in die storie of geskiedenis geld: slegs dit wat betrekking het op sy rol wat hy op aarde moet vervul, word vertel. Wat nie vertel word nie, help dus om wat wel vertel word groter reliëf te gee.

Sommige gebeurtenisse kan baie kort saamgevat word, soos sê nou maar ' $n$ reis van een plek na 'n ander wat 'n dag duur in die geskiedenis en in die verhaal in twee sinne vertel word. Hierdie samevattende dele van die geskiedenis is weer eens van minder belang en dien om die verhaal te laat versnel. 
Belangrike episodes word in 'n toneelmatige aanbieding vertel, met ander woorde dade word beskryf en woorde en gesprekke word aangehaal. Feitlik al die wonderwerke van Jesus of belangrike ontmoetings word toneelmatig aangebied. Die vertellers van die evangelieverhaal het dus uiters selektief te werk gegaan deur slegs te konsentreer op bepaalde dade en hierdie gebeure dan toneelmatig aan te bied. Weer eens pas die keuse vir die toneelmatige aanbieding presies in die Messiaanse rol van Christus. Die gelykenisse is ook voorbeelde van toneelmatige aanbieding, sodat ook die woorde van Christus die maksimale vooropstelling verkry.

Dit is baie interessant en sinvol dat daar in die evangelies van 'n ander baie gesofistikeerde tydstegniek gebruik gemaak word, naamlik dié tipe vertraging in 'n verhaal wat 'n pouse veroorsaak. Dit geld die gedeeltes waar byvoorbeeld die bergrede volledig gegee word - die vertalers noem dit 'n onderbreking van die verhaal. Hierdie gesofistikeerde tegniek val op in 'n verhaalvorm wat origens so basies en eenvoudig moontlik gehou is. Dit hang saam met die besondere karakter van die evangelies. Hierdie gedeeltes staan uit, onder andere deur die gebruikmaking van poëtiese konvensies soos metaforisering en parallelismes en moet dus met groot aandag en met baie werk van die kant van die ontvanger af gelees word. Dit lyk my 'n interessante ondersoek om te probeer nagaan waarom juis bepaalde aspekte van die evangelieboodskap gereserveer word vir hierdie nie-verhalende gedeeltes, terwyl ander gedeeltes deur middel van ' $n$ basiese verhaalvorm gekommunikeer word.

'n Laaste tydsaspek geld die frekwensie van gebeure - 'n gebeurtenis wat een keer in die geskiedenis plaasgevind het, kan meer as een keer in die verhaal vertel word; omgekeerd kan gebeurtenisse wat by herhaling in die geskiedenis plaasvind, byvoorbeeld die eet van maaltye, net een keer in die verhaal vertel word. Dit sal hier interessant wees om na te gaan waarom sekere gebeurtenisse, en watter natuurlik, deur meer as een verteller in meer as een evangelie vertel word. Dit geld ook die vraag watter tipes gebeure dalk meer kere aangehaal word as ander byvoorbeeld hoeveel keer word wonderwerke waar genesing van siekes ter sprake is, volledig vertel in vergelyking met kere waar die elemente beheer word, ensovoorts. Dit lyk my asof dié tydstegnieke wat wel in die evangelies geaktiveer word, deur die eksegeet gebruik sou kon word om sowel gemeenskaplike kenmerke van die gebeure in die afsonderlike evangelies as die groot trekke van die evangelies in vergelyking met mekaar na te vors. 


\subsection{Die verhaal en die karakterisering}

Sodra spesifieke karaktereienskappe aan akteurs toegeken word, promoveer hulle van akteurs in die storie na personasies of karakters in die verhaal. In artistieke verhale word die hoofkarakter of karakters gewoonlik as redelik volledige en gekompliseerde mense uitgebeeld met 'n vermenging van slegte en goeie eienskappe. Die leser is gewoonlik in die posisie om 'n personasie baie vollediger te leer ken as wat moontlik is in die werklikheid, aangesien hy via die verteller toegang het tot sy dade, woorde en onuitgesproke gedagtes en gevoelens. Veral in gesofistikeerde moderne verhale word 'n geslaagde karakter beskou as iemand wat oortuigend menslik kan wees en wat dus nie onvermengd goed of sleg sal wees nie. ' $n$ Minder volledig uitgebeelde karakter word gewoonlik beskryf as eendimensioneel en ' $n$ tipe.

Dit sou baie interessant wees om die karaktereienskappe van Christus te ontleed soos dit in die evangelies geopenbaar word. Daar word gewoonlik klem gelê op die volledige menswees van Christus, maar hoeveel van hierdie veronderstelde menswees word werklik in die verhaal uitgelig? Dit is eerder so dat Christus meesal juis anders optree en praat as wat van ' $n$ normale menslike mens verwag sou kon word. Wie anders sou konsekwent die Bose kon weerstaan en onophoudelik net die goeie doen? Die beeld wat die leser of ontvanger uiteindelik van Christus kry, is 'n geabstraheerde voorbeeld - nie 'n volledig menslike mens nie. Alhoewel oortuigende karakteriseringstegnieke gebruik word - openbaring deur sy dade en deur sy woorde - word hierdie karakteriseringstegnieke selektief gebruik om juis sy Messiaanse rol op aarde te belig. Met ander woorde dit gaan meer om sy aktansiële rol as om sy volledige karakter. Weer eens is hierdie nieaktivering van ' $n$ narratiewe tegniek, of dan die selektiewe aktivering daarvan, ' $n$ bate en nie ' $n$ leemte nie. ' $n$ Mens sou moes aflei dat dit vir die evangeliste gaan om 'n baie duidelike en herkenbare uiteensetting en oortuigende aanbieding van Christus se Messiaanse rol op aarde hiervoor is die aktansiële tipe 'n geskikter narratiewe tegniek as die volledige karakterisering. Weer eens is dit noodsaaklik dat die eksegeet hom sal vergewis van watter genrekonvensies gebruik word, sodat hy nie irrelevante vrae oor die verhalende karakter van die evangelies sal stel nie.

\subsection{Die verhaal en die fokalisering}

Gewoonlik word die vlakke van die vertelhandeling, narratiewe teks en 
storie ten opsigte van vertellers, fokalisators en akteurs soos volg onderskei:

$\begin{array}{lll}\begin{array}{l}\text { A vertel } \\ \text { (vertelhandeling) }\end{array} & \begin{array}{l}\text { wat B sien } \\ \text { fokalisator } \\ \text { teks/verhaal }\end{array} & \begin{array}{l}\text { wat C doen } \\ \text { akteur } \\ \text { storie }\end{array}\end{array}$

Hierdie funksies kan ò almal deur verskillende instansies uitgevoer word of hulle kan in 'n mindere of meerdere mate saamval. Ten opsigte van die evangelies val die funksies van verteller en fokalisator in sommige gevalle saam: Christus se verhaal word vertel deur die vier evangeliste soos dit deur hulleself of deur ander waargeneem is - dit is in alle gevalle veronderstel om ooggetuieverslae te wees. Christus self is die hoofakteur en die evangelistevertellers rapporteer wat $\mathrm{Hy}$ doen en sê. Die interessante van die evangelies is verder dat die vier opskrywers verskeie funksies gelyktydig vervul: Hulle is skrywers buite die narratiewe teks, vertellers-fokalisators binne die narratiewe teks en soms ook akteurs binne die vertelde geskiedenis. Die fokaliseringsaspek is veral interessant vir 'n vergelyking tussen die vier evangelies waarom en hoe word die hoofakteur en om watter effekte te bereik deur die verskillende fokalisators eenselwig of verskillend gefokaliseer?

\section{DIE NARRATIEWE TEKS EN DIE VERTELLER}

Anders as in die meeste artistieke verhale het die vertellers in die evangelies vrye toegang tot die verskillende vlakke van die teks:

- die vier evangeliste is die skrywers van die evangelies en staan dus buite die evangelies se tekstuele grense; hulle rig die evangelie aan ontvangers wat eweneens buite die tekstuele grense verkeer;

- hulle is as die primêre woordvoerders die verslaggewers oor die vertelde geskiedenis, maar hulle is terselfdertyd

- soms as newekarakters in die aktansiële rol van helpers deel van die vertelde geskiedenis;

- hulle staan vir baie groot gedeeltes die woord af aan die hoofakteur, naamlik Christus wat dan as sekondêre woordvoerder deel van die vertelde geskiedenis is;

- Hy staan ook dikwels die woord af aan tersiêre woordvoerders wat as hoofakteurs optree binne die fiktiewe gelykenisse in verhaalvorm.

Dit is natuurlik heeltemal uniek dat Christus as die verteller van 'n 
gelykenis na die gelykenis optree as 'n onderwyser wat hierdie gelykenis moet verduidelik aan die verteller wat weer die rol van Christus moet oordra. Die rol van die verteller of primêre woordvoerder is uiteraard dan meer beperk as in ' $n$ gewone artistieke verhaal waar hy normaalweg juis oor meer inligting beskik as die akteurs wat hy aan die woord kan stel soos dit hom pas. Hier word die aard van die rapportering as ' $t$ ware gerig deur die leerstellinge en uiteensettings van die hoofakteur in die vertelde geskiedenis.

\section{SLOTOPMERKINGS}

Dit is duidelik dat die verhaalstruktuur van die evangelies in baie opsigte verrassend afwyk van die artistieke strukture van narratiewe fiksionele tekste. Genrekonvensies word selektief en op 'n unieke manier benut om maksimale duidelikheid van die boodskap te verseker. Ek meen dat die literatuurteoretikus en die eksegeet in ' $n$ baie boeiende gesprek met mekaar sou kon tree oor die dekodering van die evangelieboodskap aan die hand van bepaalde narratiewe konvensies.

\section{Literatuurverwysings}

BAL, M 1978. De theorie van vertellen en verhalen: Inleiding in de narratologie. Muiderberg: Coutinho.

BREMOND, C 1966. La logique des possibles narratifs. Communications 8, 60-76.

$\mathrm{ECO}, \mathrm{U}$ 1979. The role of the reader: Explorations in the semiotics of texts. Bloomington: Indiana University Press.

GENETTE, G 1980. Narrative discourse. Ithaca, N.Y.: Cornell University Press.

GREIMAS, AJ 1966. Sémantique structurale. Paris: Larousse.

JAKOBSEN, R 1960. Concluding statement: Linguistics and poetics, in Sebeok, T, Style in language. Cambridge: MIT Press.

PROPP, V 1968. Morphology of the folktale. Austin, Texas: University of Texas Press.

RIMMON-KENAN, S 1983. Narrative fiction: Contemporary poetics. London: Methuen.

VAN LUXEMBURG, J, BAL, M \& WESTSTEIJN, WG 1983. Inleiding in de literatuurwetenschap, Muiderberg: Coutinho. 